\title{
Ecological co-benefits from sea cucumber farming: Holothuria scabra increases growth rate of seagrass
}

\author{
Jessica Arnull ${ }^{1, *}$, A. Meriwether W. Wilson ${ }^{1}$, Kitty Brayne ${ }^{3}$, Kyle Dexter ${ }^{1,2}$, \\ Angelo G. Donah ${ }^{4}$, Charlotte L. A. Gough ${ }^{3}$, Timothy Klückow ${ }^{4}$, Bryne Ngwenya ${ }^{1}$, \\ Alexander Tudhope ${ }^{1}$
}

\author{
${ }^{1}$ School of GeoSciences, University of Edinburgh, James Hutton Road, Edinburgh EH9 3FE, UK \\ ${ }^{2}$ Royal Botanic Garden Edinburgh, 20a Inverleith Row, Edinburgh EH3 5LR, UK \\ ${ }^{3}$ Blue Ventures, The Old Library, Trinity Road, Bristol BS2 0NW, UK \\ ${ }^{4}$ Blue Ventures, Villa Huguette, Lot II U 86, Cité Planton, Ampahibe, 101 Antananarivo, Madagascar
}

\begin{abstract}
Sea cucumber aquaculture is increasing in extent and importance throughout the Indo-Pacific region, supplying a luxury seafood market in Asia. In this context, the grow-out of hatchery-bred juveniles in community-farmed pens is proving to be a viable model, providing increased income security and alternative livelihood options to resource-limited communities. Here, we report a study of the impacts of such sea cucumber farming on the growth of seagrass (a favourable habitat for the animals) at a village-scale aquaculture site in southwest Madagascar. Using experiments, we found that the presence of the hatchery-bred sea cucumber Holothuria scabra (sandfish), at stocking densities of $300 \mathrm{~g} \mathrm{~m}^{-2}$ (similar to the density used in the farmed pens, but relatively high for natural populations), resulted in a large $(\sim 30 \%)$, statistically significant increase in the leaf extension rate of the locally dominant seagrass species Thalassia hemprichii. However, the other dominant seagrass species, Cymodocea serrulata, did not significantly change its leaf extension rate in the presence of $H$. scabra. Since seagrass is a globally important coastal habitat, supporting high biodiversity, carbon sequestration, shoreline stability and nursery grounds for commercial and small-scale fisheries, the positive effect of $H$. scabra farming on the growth rate of at least one dominant seagrass species implies potential important ecological cobenefits. These co-benefits of $H$. scabra farming are likely to be relevant across the tropical IndoPacific coastlines, where this species is cultured.
\end{abstract}

KEY WORDS: Holothuria scabra - Sea cucumber aquaculture - Seagrass · Thalassia hemprichii . Cymodocea serrulata $\cdot$ Madagascar $\cdot$ LMMA $\cdot$ Ecosystem services

\section{INTRODUCTION}

Holothuroids (sea cucumbers) are benthic organisms belonging to Phylum Echinodermata. They have been harvested for centuries to supply Asian seafood markets, primarily as a luxury dried food item known as bêche-de-mer or trepang (Purcell 2014, Juinio-Meñez et al. 2017). One of the most valuable of these species is Holothuria scabra Jaeger,

\footnotetext{
${ }^{*}$ Corresponding author: jessica.arnull@ed.ac.uk
}

1833 ('sandfish' or known in local dialect in SW Madagascar as 'zanga fotsy'), which inhabit shallow coastal waters such as seagrass beds across the IndoPacific (Mercier et al. 2000, Hamel et al. 2001, Purcell et al. 2012a,b). Rising demand in the 1980s led to the depletion and over-extraction of sea cucumber fisheries and natural stocks (Mercier et al. 1999). In some cases, exploitation became so severe that fisheries governance and regulatory measures alone have

() The authors 2021. Open Access under Creative Commons by Attribution Licence. Use, distribution and reproduction are unrestricted. Authors and original publication must be credited. 
been incapable of restoring populations (Mercier et al. 1999, Anderson et al. 2011, Friedman et al. 2011, Purcell et al. 2012a, Conand 2018), leading to the development of the sea cucumber aquaculture sector (Eriksson et al. 2012, Purcell et al. 2012b). Typically selling for up to US\$165 $\mathrm{kg}^{-1}$ (for specimens $<8 \mathrm{~cm}$ ) and more than US\$840 $\mathrm{kg}^{-1}$ (for specimens $>12 \mathrm{~cm}$ ) in Hong Kong or Guangzhou, H. scabra is now the most extensively cultured tropical species of sea cucumber (Purcell 2014, Juinio-Meñez et al. 2017).

In the southwest region of Madagascar, sea cucumber fishing in shallow coastal lagoons is an integral aspect of the livelihoods of the Vezo people who inhabit this region (Rasolofonirina 2007, Robinson \& Pascal 2009). Since 2009, the British-based conservation group Blue Ventures (BV) has been making considerable progress working with communities to develop an innovative sea cucumber aquaculture livelihood model in the village of Tampolove, a small Vezo fishing village situated in the protected waters of the Velondriake locally marine managed area (LMMA) (Cripps \& Harris 2009). Here, BV and the Velondriake Association have been working with the village to establish a viable community-led sea cucumber aquaculture business that allows a steady monthly income through the sale of mature adults whilst reducing wild-catch fishing pressure and potentially supporting the recovery of wild sea cucumber populations (Gardner et al. 2020).

Although the last 2 decades have seen increased efforts in sea cucumber aquaculture (e.g. Mercier et al. 1999, Lavitra et al. 2010, Purcell 2010, Hair et al. 2016, 2020, Altamirano et al. 2017, Sinsona \& Juinio-Meñez 2018), research addressing the basic biology and ecology of hatchery-bred H. scabra remains limited. Studies have identified substantial ecological impacts when benthic marine organisms are removed from a particular coastal environment (Solan et al. 2004), and given the importance of sea cucumbers in recycling and remineralising nutrients and organic matter through feeding, excretion and bioturbation activities (Purcell et al. 2016), it is reasonable to assume that both the removal and the introduction of these animals - especially at high densities - could generate considerable ecological impacts on the surrounding coastal ecosystem (Thomson 2017, Ceccarelli et al. 2018, Lee et al. 2018).

Of particular importance is the relationship that $H$. scabra have with seagrass - a favourable habitat for the animals. Sea cucumber larvae rely on seagrass for their settling cues, and the seagrass then provides the juveniles with protection from predation and a suitable substrate on which to grow (Mercier et al.
2000, Hamel et al. 2001, Wolkenhauer et al. 2010, Purcell 2012, Hair et al. 2016, Ceccarelli et al. 2018). Whilst seagrass habitats provide benefits for $H$. scabra, seagrass may also benefit from the presence of holothurians (Wolkenhauer et al. 2010). Through their diel burying cycle, species like $H$. scabra bury into the sediment, potentially having a greater impact on surface and sub-surface sediment displacement and mixing than other holothurians (Yamanouchi 1939, 1956, Mercier et al. 1999, Purcell et al. 2016). This burying has been hypothesised to increase benthic primary production by irrigating and oxygenating deeper sediment layers (Mercier et al. 1999, Purcell et al. 2016), allowing for greater belowground seagrass growth (Wolkenhauer et al. 2010, Rougier et al. 2013). This behaviour may (1) transfer or displace buried sedimentary organic matter to the sediment surface, encouraging aerobic remineralisation and (2) release nutrients trapped in interstitial waters, thereby increasing nutrient efflux to both the water and sediment columns for uptake by seagrass (Massin 1982, Uthicke 1999, Grall \& Chauvaud 2002, de Witt 2009). Similarly, the ingestion and excretion of large volumes of sediment by holothurians has been shown to enrich dissolved nutrients in the surrounding sediment (Webb et al. 1977, Conde et al. 1991, Uthicke 2001, Costa et al. 2014), which may also stimulate seagrass growth (Hughes et al. 2004). In support of this hypothesis, a 2 yr experiment carried out by Wolkenhauer et al. (2010) found that when wild H. scabra were excluded from experimental pens, seagrass productivity and biomass were diminished in some (but not all) experimental periods.

If this ecological mutualism does exist between $H$. scabra and seagrass, it is likely that under certain circumstances a greater density of $H$. scabra could be positively correlated with greater seagrass growth, as suggested by Rougier et al. (2013), noting that there is a recognised maturity-dependency on sandfish preference for seagrass (e.g. Ceccarelli et al. 2018). As seagrass meadows are considered highly productive ecosystems (Duarte \& Chiscano 1999, Hemminga \& Duarte 2000), a positive mutualism could enhance wider ecosystem benefits. Seagrass meadows provide a number of key ecological functions and services, including shoreline stabilisation, coastline protection, nutrient cycling, commercial and small-scale fisheries support, biodiversity enhancement, nursery grounds and habitats for invertebrates, fish and large predators (Hemminga \& Duarte 2000, Orth et al. 2006, Heck et al. 2008, Belshe et al. 2017) and livelihood opportunities for 
many of the world's poorest communities (Unsworth et al. 2010). As of yet, no studies have addressed the potentially important role of burying holothurians on seagrass ecosystems in the context of an aquaculture farm, where population densities tend to be higher than in natural local settings.

Here, we report a study of a village-scale, community-led aquaculture site in southwest Madagascar conducted in natural seagrass habitat. The goals were to ascertain whether the presence of hatcherybred sandfish affected growth of the dominant seagrass species in the study area, adjacent to a community $H$. scabra farming operation. We hypothesised that the addition of $H$. scabra would increase seagrass growth through increased bioturbating and burying activities, improving sediment oxygenation and enhancing organic matter remineralisation, thereby increasing primary productivity.

\section{MATERIALS AND METHODS}

\subsection{Study site}

Tampolove is a small village (population 500 people) situated on the southern shore of the Bay of
Assassins; a broad and shallow bay located $\sim 150 \mathrm{~km}$ north of Toliara in southwest Madagascar $\left(22^{\circ} 13.3^{\prime} \mathrm{S}\right.$, $43^{\circ} 16.0^{\prime} \mathrm{E}_{\text {; Fig. }}$ 1). The bay is well-flushed, with a water depth ranging to $\sim 10 \mathrm{~m}$ in the central area, a tidal range of $\sim 2.9 \mathrm{~m}$ during spring tides and $\sim 1.5 \mathrm{~m}$ during neap tides and no major freshwater inputs. On average, this region has a hot, semi-arid climate, with open water sea surface temperature (SST) typically ranging from about $24.1^{\circ} \mathrm{C}$ in August to $29.1^{\circ} \mathrm{C}$ in February (mean monthly SST 1982-2019, IGOSS$\mathrm{nmc}$; Reynolds et al. 2002). The 4 ha farm is located $\sim 750 \mathrm{~m}$ offshore from the village (Fig. 1) and operates as a no-take zone (with the exception of the principal sandfish predator, the blue swimming crab Thalamita crenata, which are removed when encountered). The boundaries are delineated by a grid of 41 farmed pens $(30 \times 30 \mathrm{~m} ;$ Fig. 2), and are used to grow out hatchery-supplied juvenile Holothuria scabra until they reach marketable size. The farm has an average water depth of $0.5 \mathrm{~m}$ relative to low water spring tide level and sits atop a thin veneer of sediment, ranging in thickness from 0.01-1.12 $\mathrm{m}$. The seabed at the site is mostly covered with seagrass with some bare sandy patches and is dominated by poorly-very poorly sorted fine sand with an average carbonate content of around $45-50 \%$. In total, 7 spe-

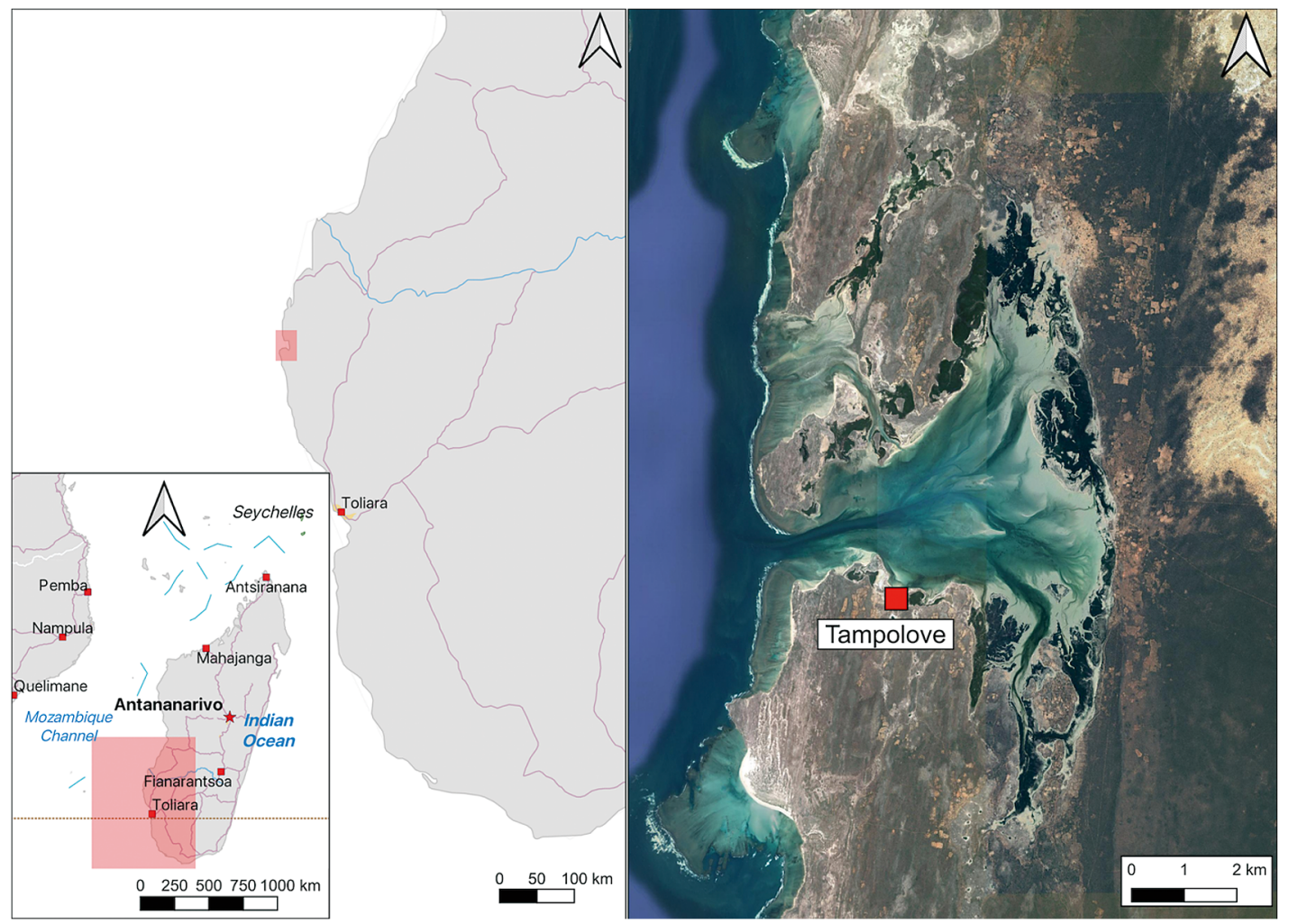

Fig. 1. Location of Tampolove within the Bay of Assassins in southwest Madagascar 


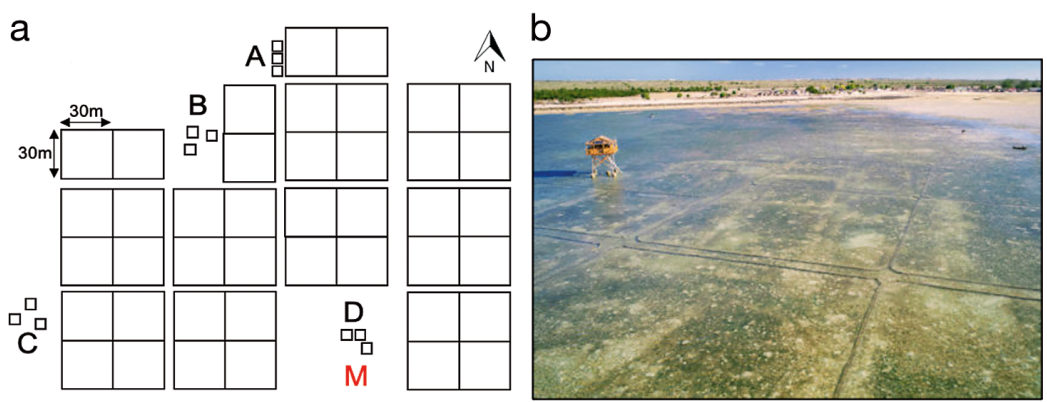

Fig. 2. (a) Tampolove site map (not to scale) with location of experimental sites indicated. M: mirador watch tower. (b) View of the aquaculture farm and mirador

cies of seagrass have been identified and are listed here in order of decreasing prevalence across the site: Thalassia hemprichii, Cymodocea serrulata, Halodule uninervis, Thalassodemdron ciliatum, Halophila ovalis, $H$. decipiens and C. rotundata.

\subsection{Experimental design}

The experiment was conducted over 2 tidal cycles during July and August 2019 and was designed to identify any differences in seagrass growth rates associated with the presence of $H$. scabra. Due to the nature of the site and experiment, all sampling occurred on foot during spring low tides. The experiment was undertaken in $4 \mathrm{~m}^{2}$ pens that were constructed (see Text S1 in the Supplement at www.int-res.com/ articles/suppl/q013p301_supp.pdf for detail) in seagrass beds at 4 (unfarmed) sites ( 3 pens site ${ }^{-1}$ ) on the periphery of the farm $(n=12)$ in areas void of wild sea cucumber populations. Site location (and pen positions therein) were chosen to ensure comparable seagrass coverage, and the position of each treatment pen was haphazardly chosen within each site. All 4 sites (identified A-D; Fig. 2) were densely covered with mixed beds of either $T$. hemprichii and $H$. uninervis (dominating Sites A and B), or C. serrulata and $H$. uninervis (dominating Sites $C$ and D). At each site, 3 different treatments were applied: control pens, void of $H$. scabra; medium-density pens, where pens were stocked with $H$. scabra at a density of $150 \mathrm{~g} \mathrm{~m}^{-2}$; and high-density pens, where pens were stocked with $H$. scabra at a density of $300 \mathrm{~g} \mathrm{~m}^{-2}$. The high-density treatment was based on the farm's optimal stocking density, which is determined by the critical biomass value of the sediment (Lavitra et al. 2010, Plotieau et al. 2013). Animals used to stock the experimental pens weighed between 30 and $150 \mathrm{~g}$ and were supplied by the hatchery used to stock the commercial pens. Whilst these sandfish were representative of the current stock intake, the experiment did not attempt to simulate the natural variability in the size of the animals usually found in the commercially farmed pens, which range from $<15 \mathrm{~g}$ to $>500 \mathrm{~g}$. Furthermore, as the experiment was based on biomass $\left(\mathrm{g} \mathrm{m}^{-2}\right)$ rather than ind. $\mathrm{m}^{-2}$, the number of animals per pen varied between and within the treatments, although care was taken to ensure the size and number of $H$. scabra was roughly consistent between pens (Table S1).

\subsection{Pen characterisation}

Prior to the experiment, data were collected for several descriptor variables for each experimental pen through visual surveys. Seagrass cover (\%) and species composition (\%) were calculated using standardized estimates from Seagrass Watch (McKenzie et al. 2001) to visually estimate seagrass cover on a scale of $1-100 \%$. Sediment thickness (m) and seaand rockbed elevation were calculated by measuring sediment and water depth and then calibrating against a local tidal datum (spring low tide level observed during the experiment). The number and type of holothurian and thalassinidean shrimp sediment mounds (species unknown and both of which may have an impact on sediment oxygenation) present within each pen was recorded. Sediment samples were collected from the top $5 \mathrm{~cm}$ of sediment prior to the experiment for subsequent analysis of sediment grain size and sediment organic carbon content $\left(\mathrm{C}_{\text {org }} \%\right)$.

\subsection{Seagrass growth}

Seagrass growth was measured by determining the vertical growth in seagrass blades over the course of 3 spring tides. Growth was measured in $T$. hemprichii blades at Sites A and B, and in C. serrulata blades at Sites $\mathrm{C}$ and D (even where $T$. hemprichii dominated cover in pens C1, C2 and D1; see Table 1). Following the 'hole-punch' method detailed by Zieman (1974), seagrass blades were stapled at the base of the leaf, left to grow and harvested after $14 \mathrm{~d}$. The distance from the base of the leaf to the staple was measured wet $(\mathrm{cm})$, allowing for leaf extension rates to be expressed as $\mathrm{cm}$ shoot $^{-1} \mathrm{~d}^{-1}$. 
To account for any between- or within-site variation in environmental conditions, seagrass extension rates were first calculated without the presence of $H$. scabra over the first tidal cycle (pre-stocking). In each experimental pen, a small area of $20 \mathrm{~cm}^{2}$ was haphazardly marked (ensuring sufficient coverage of the corresponding seagrass species at the respective sites) using a quadrat and small metal rods. Within these $20 \mathrm{~cm}^{2}$ areas, a minimum of 25 seagrass blades were marked individually with a staple and their number recorded, although due to the heterogeneity in seagrass cover, this number varied between pens; 14 d later, all stapled blades were harvested and stored in water for subsequent measurement. Pens were then stocked with the sea cucumbers (at the respective densities) and the process was repeated for another $20 \mathrm{~cm}^{2}$ area within the pens over the next tidal cycle (post-stocking). The dynamic coastal setting meant that the blades naturally suffered varying degrees of loss (e.g. through grazing or disturbance), meaning not all blades that were stapled survived the experiment. The average number of stapled blades retrieved at the end of the experiment was 25 but ranged from 16-32 among pens.

\subsection{Elemental and sediment grain size analysis}

Sediment samples were analysed for total $\mathrm{C}_{\text {org }}(\%)$ content using an organic elemental analyser (Carlo Erba NA 2500, Eager 300 software). Sediment grain size was measured using a Beckman-Coulter LS 230 laser particle size analyser equipped with a fluid module (see Text S2).

\subsection{Statistical analyses}

All descriptive statistics are presented as means \pm SE unless stated otherwise. Given non-normality of data and small sample sizes, non-parametric MannWhitney $U$-tests were used to identify any significant within-site and between-site differences for prestocking data as well as any significant differences between pre-stocking and post-stocking control data. Linear regression was used to determine relationships between pen characteristics and seagrass leaf growth rates. To assess the impact of stocking density, we constructed mixed effects models with the growth of individual grass blades ( $\mathrm{cm}$ shoot ${ }^{-1}$ $\mathrm{d}^{-1}$ ) as the response variable, holothurian density as a fixed effect (control, medium and high) and site as a random effect (A, B, C and D). Model residuals were checked for normality and homoscedasticity with respect to fitted values and explanatory variables. To evaluate the importance of holothurian density, we compared the values of Akaike's information criterion corrected for small sample size $\left(\mathrm{AIC}_{\mathrm{C}}\right)$ of a model with holothurian density as a fixed effect versus a null model without. A difference in $\mathrm{AIC}_{\mathrm{C}}$ values greater than 2 can be taken as evidence that there is a statistically detectable effect (Burnham \& Anderson 2004). We conducted additional tests on the pairs of sites with similar dominating seagrass species (i.e. just Sites A and B, and just Sites C and D). Finally, to assess if any significant effects of holothurian density were present at medium densities or just at high densities, we constructed similar models but grouped the control with medium-density plots and alternatively grouped the medium-density and high-density plots. The $\mathrm{AIC}_{\mathrm{C}}$ values of these models were compared to the model with 3 separate density categories. Significance was accepted at $\mathrm{p} \leq 0.05$, and analyses were conducted in R v.4.0.2.

\section{RESULTS}

\subsection{Pen characterisation}

Environmental conditions were similar among pens within the same site, though there were some noteworthy between-site differences. Site A was most anomalous, with considerably lower seagrass cover and a thinner sediment layer than the other 3 sites. Sites A and B had greater average water depth (lower seabed elevations) than Sites C and D. Seagrass species composition within Sites C and D were also considerably more varied than those from Sites A and B (Table 1), with pens C1, C2 and D1 dominated by Thalassia hemprichii. Despite these differences, linear regression analyses indicated no significant relationships between pen characteristics and seagrass leaf extension rates.

\subsection{Seagrass growth}

Due to the physiological differences in the seagrass species, analyses were carried out separately for the 2 pairs of sites (A-B and $C-D)$, allowing differences in growth rates between species to be measured. During pre-stocking, no statistically significant differences were detected between pens within a single site. When control-pen data were compared between the pre- and post-stocking growing phases (thus 
Table 1. Descriptor variables characterising the environmental conditions of each individual aquaculture pen. $\mathrm{C}_{\text {org }}$ : organic carbon. Th: Thalassia hemprichii; Cs: Cymodocea serrulata; Hu: Halodule uninervis; S: shrimp mound; H: holothurian mound. Seabed and rock elevation data are relative to low water spring tide of $0.35 \mathrm{~m}$ (17 May 2018 at 14:15 h)

\begin{tabular}{|c|c|c|c|c|c|c|c|c|}
\hline Pen & $\begin{array}{c}\text { Seagrass } \\
\text { cover }(\%)\end{array}$ & $\begin{array}{c}\text { Species } \\
\text { composition } \\
(\%)\end{array}$ & $\begin{array}{l}\text { Number } \\
\text { of } \\
\text { mounds }\end{array}$ & $\begin{array}{c}\text { Total } C_{\text {org }} \\
(\%)\end{array}$ & $\begin{array}{l}\text { Sediment grain } \\
\text { size (median } \\
\text { value; } \mu \mathrm{m})\end{array}$ & $\begin{array}{c}\text { Sediment } \\
\text { depth }\left(\mathrm{m}_{;} \text {mean }\right. \\
\pm \mathrm{SE}, \mathrm{n}=3)\end{array}$ & $\begin{array}{l}\text { Seabed } \\
\text { elevation } \\
(\mathrm{m})\end{array}$ & $\begin{array}{l}\text { Rock } \\
\text { elevation } \\
\text { (m) }\end{array}$ \\
\hline A1 & 78 & 94:6 (Th:Hu) & $1(S)$ & 0.5 & 131 & $0.17 \pm 0.003$ & 0.08 & -0.05 \\
\hline A2 & 75 & 95:5 (Th:Hu) & $1(H)$ & 0.6 & 155 & $0.14 \pm 0.003$ & & \\
\hline A3 & 65 & 92:8 (Th:Hu) & 0 & 0.7 & 144 & $0.11 \pm 0.002$ & & \\
\hline B1 & 95 & 95:5 (Th:Hu) & $2(S)$ & 0.7 & 132 & $0.35 \pm 0.006$ & 0.05 & -0.14 \\
\hline B2 & 94 & 90:10 (Th:Hu) & 0 & 0.8 & 125 & $0.28 \pm 0.004$ & & \\
\hline B3 & 94 & 92:8 (Th:Hu) & $1(H)$ & 0.7 & 124 & $0.31 \pm 0.002$ & & \\
\hline $\mathrm{C} 1$ & 93 & 85:10:5 (Th:Cs:Hu) & $2(S)$ & 0.9 & 131 & $0.30 \pm 0.003$ & 0.25 & -0.10 \\
\hline $\mathrm{C} 2$ & 80 & 70:20:10 (Th:Cs:Hu) & $1(S)$ & 1.0 & 113 & $0.23 \pm 0.003$ & & \\
\hline $\mathrm{C} 3$ & 95 & 35:50:15 (Th:Cs:Hu) & $1(H)$ & 0.9 & 121 & $0.20 \pm 0.003$ & & \\
\hline D1 & 92 & 65:5:30 (Th:Cs:Hu) & 0 & 0.8 & 131 & $0.27 \pm 0.002$ & 0.23 & 0.01 \\
\hline D2 & 75 & 10:65:25 (Th:Cs:Hu) & $2(S)$ & 0.7 & 115 & $0.29 \pm 0.003$ & & \\
\hline D3 & 95 & 20:75:5 (Th:Cs:Hu) & 0 & 0.8 & 106 & $0.22 \pm 0.003$ & & \\
\hline
\end{tabular}

accounting for external factors that may have influenced growth rates between the 2 sampling periods), there were no statistically significant differences in seagrass growth rates between the 2 growing phases for either species (T. hemprichii: $U=1467, \mathrm{p}=0.670$, $\mathrm{n}=111$; Cymodocea serrulata: $U=924.5, \mathrm{p}=0.295$, $\mathrm{n}=92$ ). These observations improve confidence in attributing any observed between-treatment differences in seagrass growth rate within sites during the post-stocking phase to the addition of sea cucumbers. During post-stocking, in both the medium- and high-density pens, leaf extension rates increased for T. hemprichii but not C. serrulata (Fig. 3). The highdensity pens displayed the highest growth rates for T. hemprichii $\left(0.307 \pm 0.023 \mathrm{~cm} \mathrm{shoot}^{-1} \mathrm{~d}^{-1}\right)$, which was $\sim 33 \%$ faster on average than that observed in the controls $\left(0.231 \pm 0.021 \mathrm{~cm} \mathrm{shoot}^{-1} \mathrm{~d}^{-1}\right)$. The addition of Holothuria scabra, irrespective of density, pro-

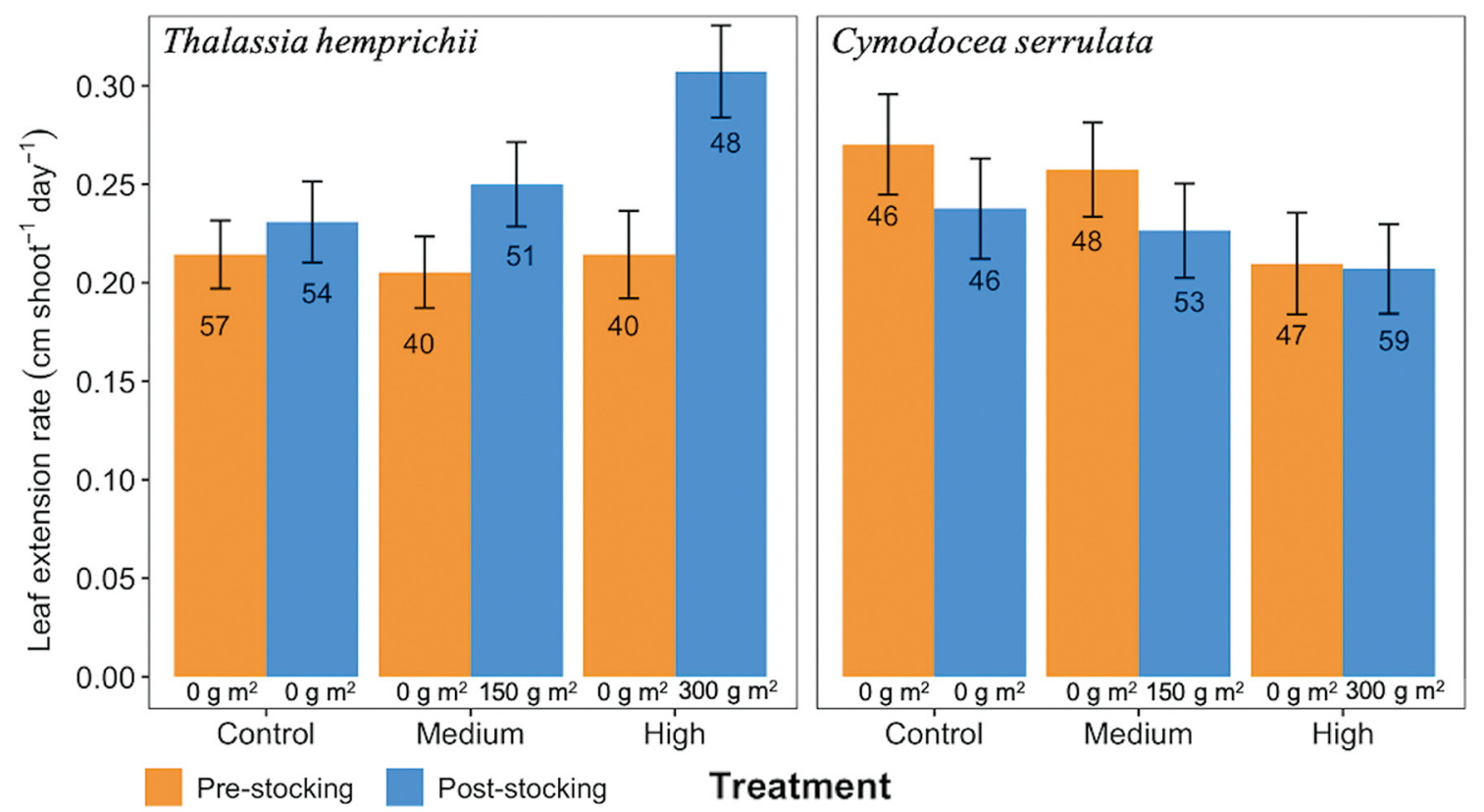

Fig. 3. Mean $( \pm \mathrm{SE})$ seagrass leaf extension rates for the 2 most dominant seagrass species. Stocking densities (g Holothuria scabra $\mathrm{m}^{-2}$ ) used in the 3 treatments are shown below each bar for the 2 growing phases: pre-stocking and post-stocking. Each bar represents the mean growth rate of all individual seagrass blades from Sites A and B for Thalassia hemprichii and from

Sites C and D for Cymodocea serrulata for each treatment (number of observations are shown underneath error bars) 
duced a negligible effect on growth rates for C. serrulata, with the high-density pens producing somewhat (but not statistically significantly) lower growth rates than both the control and medium pens.

Our mixed effects statistical models indicate that holothurian stocking density did have a statistically detectable effect on the growth of $T$. hemprichii (Table $2 ; \Delta \mathrm{AIC}_{\mathrm{C}}$ of 2.5 between null model and full model), but not $C$. serrulata. This effect seems to be driven by higher seagrass growth in the high-density plots since grouping the medium-density plots with the control plots into a single category improved the model (i.e. lowered the $\mathrm{AIC}_{\mathrm{C}}$ values; Table 2). Conversely, when we conducted analyses across all 4 groups of pens (i.e. pens dominated by T. hemprichii and those dominated other seagrass species), we did not detect any statistical effect of holothurian density (null model had a lower $\mathrm{AIC}_{\mathrm{C}}$ value by 0.7 units). To emphasise this result, when the analysis was restricted to just $C$. serrulata growth, the null model outperformed the full model by $4.1 \mathrm{AIC}_{\mathrm{C}}$ units.

\section{DISCUSSION}

The experimental data indicate that Holothuria scabra have a net overall positive effect on seagrass leaf growth but that this effect is conditional on 2 considerations. Firstly, the data suggest that there is some threshold effect of $H$. scabra density on seagrass growth as only the high-density pens experienced a large $(\sim 30 \%)$ and statistically significant increase in growth rates of Thalassia hemprichii. This may imply that only at certain density will $H$. scabra make a notable difference on the local environment. Secondly, it suggests that this relationship may only hold true for certain species of seagrass. This may be due to differing functional traits of the 2 species,

Table 2. Model performance for mixed effect models to evaluate the effect of holothurian stocking density on seagrass growth for Sites A and B only (Thalassia hemprichii). Differences in Akaike's information criterion corrected for small sample size $\left(\Delta \mathrm{AIC}_{\mathrm{C}}\right)$ values are given relative to the best-performing model, which itself has a $\Delta \mathrm{AIC}_{\mathrm{C}}$ value of 0 ( $p<0.05)$. C: control (no Holothuria scabra); M: medium stocking density; $\mathrm{H}$ : high stocking density

\begin{tabular}{|lcc|}
\hline Model & AIC $_{\mathrm{C}}$ & $\Delta \mathrm{AIC}_{\mathrm{C}}$ \\
\hline Null model (only random effects) & -1128.0 & 3.7 \\
Model with C, M and H separate & -1130.5 & 1.2 \\
Model grouping M and H vs. C & -1129.9 & 1.8 \\
Model grouping C and M vs. H & -1131.7 & 0 \\
\hline
\end{tabular}

which may have led to different growth rate responses that were not fully captured within this study. As there are many different aspects to plant expansion and maturation, it is difficult to capture a holistic picture of whole plant growth with just one method. Future experiments would benefit from measuring belowground biomass growth through rhizome marking and plastochrone interval. Ranges in seagrass growth observed through the experimental period correspond reasonably well with maximum growth rates found in other studies for $T$. hemprichii (e.g. Ogden \& Ogden 1982, Duarte 1991, Erftemeijer \& Herman 1994, Lin \& Shao 1998), but for Cymodocea serrulata, our growth ranges were more variable compared to other studies (e.g. Udy \& Dennison 1997, Kamal et al. 1999, de Boer 2000, Yamada et al. 2018).

Bioturbators are a natural component of seagrass ecosystems, providing essential services within seagrass meadows, without which they would struggle to exist (Kristensen et al. 2012, Thomson 2017). Whilst the role of sea cucumbers as bioturbators is less well understood, these results indicate that some species like $H$. scabra could have greater ecosystem value than previously thought through their alteration of sediment biology, geochemistry and physical structure. For seagrasses, sustained functioning of roots and rhizomes depends on an adequate supply of oxygen (Duarte et al. 1998). Therefore, it is likely that burying activities carried out by $H$. scabra destabilise the stratified sediment causing increased aeration, thus increasing sediment oxygen supply and contributing to plant growth. These actions may also potentially release organic material and nutrients trapped in sediment porewaters back into the water column (Massin 1982, Uthicke 1999), thereby providing additional nutrients for seagrass. Likewise, the ingestion of large volumes of organic compounds contained within subsurface sediments and subsequent excretion of this material on the seabed results in the recycling of nutrients (particularly ammonium; cf. Uthicke 2001 for Holothuria atra) back into the water column and sediments (Webb et al. 1977, Massin 1982, Wainright 1990, Conde et al. 1991, Uthicke 2001), thereby stimulating seagrass growth (Hughes et al. 2004, de Witt 2009, Costa et al. 2014).

To more fully constrain and understand the impact of farmed H. scabra on seagrass growth and productivity, future studies would benefit from considering 3 additional factors that were beyond the scope of the current study. Firstly, estimation of changes in root and rhizome biomass and production to give a more complete picture of the impacts of total seagrass pro- 
ductivity. Secondly, undertaking multi-year experiments to assess long-term impacts. And, finally, greater replication (including more experimental pens) to increase statistical confidence and help rule out the possibility of 'non-demonic' intrusion (sensu Hurlbert 1984) influencing the interpretation of observed differences in growth rates.

\section{CONCLUSIONS}

This study found that Holothuria scabra, stocked at the relatively high population density used in aquaculture pens, significantly increased the growth rate of a common seagrass species. Since seagrass ecosystems are considered to be amongst the most productive and diverse on earth (Belshe et al. 2017, Unsworth et al. 2010) but are also threatened globally by human activities (Wylie et al. 2016), the positive impact of $H$. scabra aquaculture on growth rates raises the possibility of important ecological cobenefits. The sea cucumber farm at Tampolove operates under a strict 'no-take-zone' policy and can be viewed as 'non-invasive' (i.e. the farm requires no inputs such as feed and uses a native and endangered species that were previously highly abundant in this area). Therefore, not only is the farm offering an alternative livelihood, but the high density of farmed $H$. scabra may simultaneously protect, conserve and even 'boost' the seagrass habitat, with potential knock-on effects to recovery of local fish stocks and wild sandfish populations. This finding has relevance to sandfish farming across many regions of the tropical Indo-Pacific.

Acknowledgements. This research was conducted as part of a joint research project between the University of Edinburgh and Blue Ventures and was co-funded by the Prince Albert II of Monaco Foundation, Project No. 2505: Community-Based Aquaculture as a Catalyst for Locally Managed Marine Areas: Developing a Scalable Framework for Economic and Environmental Sustainability. We are very grateful to the Blue Ventures staff, whose guidance in the field was invaluable (in particular to Godard Diome, Feliny Bino, Alexandre Razfimandimby and Marceline 'Kokoly' Narindra) and also to Amber Carter, Kathryn Taylor, Mario Ray and Seb Hennige for field assistance and Gavin Sim for assistance with sediment analyses. We are also greatly appreciative to the reviewers, whose constructive comments and suggestions helped us significantly improve the manuscript.

\section{LITERATURE CITED}

Altamirano JP, Recente CP, Rodriguez JCJ (2017) Substrate preference for burying and feeding of sandfish Holothuria scabra juveniles. Fish Res 186:514-523
Anderson SC, Flemming JM, Watson R, Lotze HK (2011) Serial exploitation of global sea cucumber fisheries. Fish Fish 12:317-339

Belshe EF, Mateo MA, Gillis L, Zimmer M, Teichberg M (2017) Muddy waters: Unintentional consequences of blue carbon research obscure our understanding of organic carbon dynamics in seagrass ecosystems. Front Mar Sci 4:125

Burnham KP, Anderson DR (2004) Multimodel inference: understanding AIC and BIC in model selection. Sociol Methods Res 33:261-304

Ceccarelli DM, Logan M, Purcell SW (2018) Analysis of optimal habitat for captive release of the sea cucumber Holothuria scabra. Mar Ecol Prog Ser 588:85-100

Conand C (2018) Tropical sea cucumber fisheries: changes during the last decade. Mar Pollut Bull 133:590-594

Conde JE, Diaz H, Sambrano A (1991) Disintegration of holothurian fecal pellets in beds of the seagrass Thalassia testudinum. J Coast Res 7:853-862

Costa V, Mazzola A, Vizzini S (2014) Holothuria tubulosa Gmelin 1791 (Holothuroidea, Echinodermata) enhances organic matter recycling in Posidonia oceanica meadows. J Exp Mar Biol Ecol 461:226-232

Cripps G, Harris A (2009) Community creation and management of the Velondriake marine protected area. Blue Ventures Conservation Report. Blue Ventures Conservation, London

de Boer WF (2000) Biomass dynamics of seagrasses and the role of mangrove and seagrass vegetation as different nutrient sources for an intertidal ecosystem. Aquat Bot 66:225-239

de Witt TH (2009) The effects of bioturbation and bioirrigation on seagrasses. In: Nelson WG (ed) Seagrasses and protective criteria: a review and assessment of research status. US Environmental Protection Agency, Newport, OR, p 176-205

Duarte CM (1991) Allometric scaling of seagrass form and productivity. Mar Ecol Prog Ser 77:289-300

Duarte CM, Chiscano CL (1999) Seagrass biomass and production: a reassessment. Aquat Bot 65:159-174

Duarte CM, Merino M, Agawin NSR, Uri J and others (1998) Root production and belowground seagrass biomass. Mar Ecol Prog Ser 171:97-108

Erftemeijer PL, Herman PM (1994) Seasonal changes in environmental variables, biomass, production and nutrient contents in two contrasting tropical intertidal seagrass beds in South Sulawesi, Indonesia. Oecologia 99: 45-59

Eriksson H, Robinson G, Slater M, Troell M (2012) Sea cucumber aquaculture in the western Indian Ocean: challenges for sustainable livelihood and stock improvement. Ambio 41:109-121

Friedman K, Eriksson H, Tardy E, Pakoa K (2011) Management of sea cucumber stocks: patterns of vulnerability and recovery of sea cucumber stocks impacted by fishing. Fish Fish 12:75-93

Gardner CJ, Cripps G, Day LP, Dewar K and others (2020) A decade and a half of learning from Madagascar's first locally managed marine area. Conserv Sci Prac 2:e298

Grall J, Chauvaud L (2002) Marine eutrophication and benthos: the need for new approaches and concepts. Glob Change Biol 8:813-830

Hair C, Mills DJ, McIntyre R, Southgate PC (2016) Optimising methods for community-based sea cucumber ranching: experimental releases of cultured juvenile Holo- 
thuria scabra into seagrass meadows in Papua New Guinea. Aquacult Rep 3:198-208

Hair C, Foale S, Daniels N, Minimulu P, Aini J, Southgate PC (2020) Social and economic challenges to community-based sea cucumber mariculture development in New Ireland Province, Papua New Guinea. Mar Policy 117:103940

Hamel JF, Conand C, Pawson DL, Mercier A (2001) The sea cucumber Holothuria scabra (Holothuroidea: Echinodermata): its biology and exploitation as beche-de-mer. Adv Mar Biol 41:129-223

Heck KL Jr, Carruthers TJB, Duarte CM, Hughes AR, Kendrick G, Orth RJ, Williams SW (2008) Trophic transfers from seagrass meadows subsidize diverse marine and terrestrial consumers. Ecosystems 11:1198-1210

Hemminga MA, Duarte CM (2000) Light, carbon and nutrients. In: Hemminga MA, Duarte CM (eds) Seagrass ecology. Cambridge University Press, Cambridge, p 99-145

Hughes AR, Bando KJ, Rodriguez LF, Williams SL (2004) Relative effects of grazers and nutrients on seagrasses: a meta-analysis approach. Mar Ecol Prog Ser 282:87-99

Hurlbert SH (1984) Pseudoreplication and the design of ecological field experiments. Ecol Monogr 54:187-211

Juinio-Meñez MA, Tech ED, Ticao IP, Gorospe JR, Edullantes CMA, Rioja RAV (2017) Adaptive and integrated culture production systems for the tropical sea cucumber Holothuria scabra. Fish Res 186:502-513

Kamal A, Misri K, Japar S, Hishamuddin O, Hidir H (1999) Leaf growth, production and ecological aspects of toothed seagrass Cymodocea serrulata (R. Br.) Aschers. et Magnus at Port Dickson, Negeri Sembilan, Malaysia. In: International Conference on the International Oceanographic Data and Information Exchange in the Western Pacific (IODE-WESTPAC-ICIWP '99), Langkawi (Malaysia), 1-4 November 1999. Intergovernmental Oceanographic Commission of UNESCO, Paris, p 173-184

Kristensen E, Penha-Lopes G, Delefosse M, Valdemarsen T, Quintana CO, Banta GT (2012) What is bioturbation? The need for a precise definition for fauna in aquatic sciences. Mar Ecol Prog Ser 446:285-302

Lavitra T, Rasolofonirina R, Eeckhaut I (2010) The effect of sediment quality and stocking density on survival and growth of the sea cucumber Holothuria scabra reared in nursery ponds and sea pens. West Indian Ocean J Mar Sci 9:153-164

Lee S, Ford AK, Mangubhai S, Wild C, Ferse SC (2018) Effects of zanga (Holothuria scabra) removal on shallowwater sediments in Fiji. PeerJ 6:47-73

Lin HJ, Shao KT (1998) Temporal changes in the abundance and growth of intertidal Thalassia hemprichii seagrass beds in southern Taiwan. Bot Bull Acad Sin 39:191-198

Massin C (1982) Effects of feeding on the environment: Holothuroidea. In: Jangoux M, Lawrence JM (eds) Echinoderm nutrition. AA Balkema, Rotterdam, p 493-497

McKenzie LJ, Campbell SJ, Roder CA (2001) SeagrassWatch: manual for mapping \& monitoring seagrass resources by community (citizen) volunteers. QFS, NFC, Cairns

Mercier A, Battaglene SC, Hamel JF (1999) Daily burrowing cycle and feeding activity of juvenile sea cucumbers Holothuria scabra in response to environmental factors. J Exp Mar Biol Ecol 239:125-156

Mercier A, Battaglene SC, Hamel JF (2000) Settlement preferences and early migration of the tropical sea cucumber Holothuria scabra. J Exp Mar Biol Ecol 249:89-110
Ogden JC, Ogden NB (1982) A preliminary study of two representative seagrass communities in Palau, Western Caroline Islands (Micronesia). Aquat Bot 12:229-244

Orth RJ, Carruthers TJ, Dennison WC, Duarte CM and others (2006) A global crisis for seagrass ecosystems. Bioscience 56:987-996

Plotieau T, Baele JM, Vaucher R, Hasler A, Kounad D, Eeckhaut I (2013) Analysis of the impact of Holothuria scabra intensive farming on sediment. Cah Biol Mar 54:703-711

Purcell SW (2010) Diel burying by the tropical sea cucumber Holothuria scabra: effects of environmental stimuli, handling and ontogeny. Mar Biol 157:663-671

Purcell SW (2012) Principles and science of stocking marine areas with sea cucumbers. In: Hair CA, Pickering TD, Mills DJ (eds) Asia-Pacific tropical sea cucumber aquaculture. ACIAR Proceedings No. 136. Australian Centre for International Agricultural Research, Canberra, p 92-103

Purcell SW (2014) Value, market preferences and trade of bêche-de-mer from Pacific Island sea cucumbers. PLOS ONE 9:e95075

Purcell SW, Hair CA, Mills DJ (2012a) Sea cucumber culture, farming and sea ranching in the tropics: progress, problems and opportunities. Aquaculture 368369:68-81

Purcell SW, Samyn Y, Conand C (2012b) Commercially important sea cucumbers of the world. FAO Species Catalogue for Fishery Purposes No. 6. FAO, Rome

Purcell SW, Conand C, Uthicke S, Byrne M (2016) Ecological roles of exploited sea cucumbers. Oceanogr Mar Biol Annu Rev 54:367-386

Rasolofonirina R (2007) Sea cucumbers in Madagascar. In: Conand C, Muthiga N (eds) Commercial sea cucumbers: a review for the Western Indian Ocean. Western Indian Ocean Marine Science Association (WIOMSA), Nairobi, p 30-38

Reynolds RW, Rayner NA, Smith TM, Stokes DC, Wang W (2002) An improved in situ and satellite SST analysis for climate. J Clim 15:1609-1625

Robinson G, Pascal B (2009) From hatchery to communityMadagascar's first village-based holothurian mariculture programme. SPC Beche-de-mer Inf Bull 29:38-43

Rougier A, Ateweberhan M, Harris A (2013) Strategies for improving survivorship of hatchery-reared juvenile Holothuria scabra in community-managed sea cucumber farms. SPC Beche-de-mer Inf Bull 33:14-22

Sinsona MJ, Juinio-Meñez MA (2018) Effects of sediment enrichment with macroalgae, Sargassum spp., on the behavior, growth, and survival of juvenile sandfish, Holothuria scabra. Aquacult Rep 12:56-63

Solan M, Cardinale BJ, Downing AL, Engelhardt KAM, Ruesink JL (2004) Extinction and ecosystem function in the marine benthos. Science 306:1177-1180

Thomson ACG (2017) The role of bioturbators in seagrass blue carbon dynamics. PhD dissertation, University of Technology, Sydney

Udy JW, Dennison WC (1997) Growth and physiological responses of three seagrass species to elevated sediment nutrients in Moreton Bay, Australia. J Exp Mar Biol Ecol 217:253-277

Unsworth RK, Cullen LC, Pretty JN, Smith DJ, Bell JJ (2010) Economic and subsistence values of the standing stocks of seagrass fisheries: potential benefits of no-fishing marine protected area management. Ocean Coast Manage $53: 218-224$ 
Uthicke S (1999) Sediment bioturbation and impact of feeding activity of Holothuria (Halodeima) atra and Stichopus chloronotus, two sediment feeding holothurians, at Lizard Island, Great Barrier Reef. Bull Mar Sci 64: 129-141

Uthicke S (2001) Nutrient regeneration by abundant coral reef holothurians. J Exp Mar Biol Ecol 265:153-170

Wainright SC (1990) Sediment-to-water fluxes of particulate material and microbes by resuspension and their contribution to the planktonic food web. Mar Ecol Prog Ser 62: 271-281

Webb KL, D'Elia CF, Dupaul WD (1977) Biomass and nutrition flux measurements on Holothuria atra populations on windward reef flats at Enewetak, Marshall Islands. Proc $3^{\text {rd }}$ Int Coral Reef Symp, Miami 1: 410-415

Wolkenhauer SM, Uthicke S, Burridge C, Skewes T, Pitcher R (2010) The ecological role of Holothuria scabra (Echin-

Editorial responsibility: Catriona MacLeod,

Hobart, Tasmania, Australia

Reviewed by: 2 anonymous referees odermata: Holothuroidea) within subtropical seagrass beds. J Mar Biol Assoc UK 90:215-223

Wylie L, Sutton-Grier AE, Moore A (2016) Keys to successful blue carbon projects: lessons learned from global case studies. Mar Policy 65:76-84

Yamada H, Nakamoto K, Hayakawa J, Kawamura T, Kon K, Shimabukuro H, Fukuoka K (2018) Seasonal variations in leaf growth of Cymodocea serrulata in subtropical seagrass meadows. Fish Sci 84:461-468

Yamanouchi T (1939) Ecological and physiological studies on the holothurians in the coral reef of Palao Islands. Palao Trop Biol Stn Stud 25:603-634

Yamanouchi $\mathrm{T}$ (1956) The daily activity rhythms of the holothurians in the coral reef of Palao Islands. Publ Seto Mar Biol Lab 5:347-362

Zieman JC (1974) Methods for the study of the growth and production of turtle grass, Thalassia testudinum König. Aquaculture 4:139-143

Submitted: December 3, 2020

Accepted: June 1, 2021

Proofs received from author(s): August 6, 2021 